COBISS: 1.08

\title{
KARST TYPES IN BULGARIA
}

\section{TIPI KRASA V BOLGARIJI}

DORA ANGELOVA ${ }^{1}$

${ }^{1}$ Geological Institute, Bulgarian Academy of Sciences, Acad. G. Bonchev St., Bl. 24, 1113 SOFIA, BULGARIA, e-mail: doraangelova@hotmail.com

Prejeto / received: 30. 9. 2002 
Abstract

UDC: $551.44(497.2)$

\section{Dora Angelova: Karst types in Bulgaria}

The karst in Bulgaria occupies an area of $26170 \mathrm{~km}^{2}$ or $22.7 \%$ of the territory of the country. The karst water resources are estimated to be 2.3 billion $\mathrm{m}^{3}$ or $11.6 \%$ of the total water resources of the country. The interest in karst in Bulgaria has become higher during the last years because there are a number of practical problems that have to be solved. Karst in Bulgaria is characterized by great diversity due to the complex combination of factors (geological, tectonic, geomorphologic, hydrological and hydrogeological, climatic, etc.) and to the geodynamic development of this part of Europe. This work presents a new zoning of karst in Bulgaria. The following types have been distinguished: plain karst (the Danubian Plain); marine and transformed marine karst into plain and plain-marine karst (Black Sea subaqual and subareal plain); plateau-like karst (the Fore Balkan) and mountainous karst. The karst wetlands and karst phenomena provoked by paleoearthquakes are separately outlined and sample models for the different karst types, genesis, dynamics, lithostructural control, relations, etc. are presented.

Key words: karst types, paleo and neokarst, zoning, Bulgaria.

Izvleček

UDK: 551.44(497.2)

\section{Dora Angelova: Tipi krasa v Bolgariji}

Kras v Bolgariji obsega $26170 \mathrm{~km}^{2}$ oziroma 22,7 \% celotnega ozemlja. Kraški vodni viri so ocenjeni na 2,3 milijarde $\mathrm{m}^{3}$, kar predstavlja $11,6 \%$ vseh vodnih virov v državi. Zanimanje za bolgarski kras se je povečalo v zadnjih letih zaradi reševanja vsakdanjih vprašanj. Za ta kras je značilna velika raznolikost zaradi prepletanja različnih dejavnikov (geoloških, tektonskih, geomorfoloških, hidroloških in hidrogeoloških, klimatskih, itd.) in skladno z geodinamičnim razvojem tega dela Evrope. Pričujoče delo predstavlja novo delitev krasa v Bolgariji. Avtorica loči sledeče tipe: ravninski kras (Donavska nižina), morski kras, v ravninskega spremenjeni morski kras in ravninsko-morski kras (črnomorska podvodna in kopna ravnina); planotasti kras (Predbalkan) in gorski kras. Posebej obravnava kraška močvirja in kraške pojave, ki so jih povzročili potresi v geološki preteklosti. Kot primer so predstavljeni tudi modeli različnih tipov krasa, njihov nastanek, dinamika, vpliv kamninske strukture, medsebojni odnosi, itd.

Ključne besede: tipi krasa, paleo- in neokarst, delitev krasa, Bolgarija. 


\section{INTRODUCTION}

The karst in Bulgaria occupies an area of $26170 \mathrm{~km}^{2}$ or $22.7 \%$ of the territory of the country (Popov 1970). The karst water resources are estimated to be 2.3 billion $\mathrm{m}^{3}$ or $11.6 \%$ (Kehaiov \& Zyapkov 1995). Karst in Bulgaria is characterized by great diversity due to the complex combination of the factors and conditions of its formation (geological, tectonic, geomorphologic, hydrological and hydrogeological, climatic, etc.) and to the geodynamic development. Regardless of the fact that karst is well studied, there are still fundamental problems in karstology that have not been solved as a whole. In 1970 and 1976 Popov made the first zoning of surface and underground karst in Bulgaria according to the geological base. Many new data have been established recently for the specific geological-tectonic structures and karst domains, which provide the grounds of performing a new zoning (Fig. 1). The present work reflects the results from the preliminary zoning of karst in Bulgaria.

\section{KARST TYPES AND REGIONAL CHARACTERISTICS}

The karst in Bulgaria is well developed in carbonate rocks and complexes of different age. They have various thickness and tectonic processing and have originitated under different geodynamic circumstances. The karst types are surface and underground, paleo- and neokarst (covered and bare), structural, ore bearing, etc.

Plain Karst. The karst in the Danubian Plain is a typical plain karst (Fig. 1). About $70 \%$ of the karstified areas in Bulgaria are of this type. It results from the development of the Tethys and Paratethys (Yaranov 1959; Stanev 1970; Krastev 1974, 1978 a,b; Stanev \& Trashliev 1989; Angelova 1999 a,b 2001; Angelova \& Spasov 2002). The favourable historical development of karst has been enhanced by: the low inclination of the rock complexes prone to karstification $\left(3-10^{\circ}\right)$, the plain relief (altitude of up to $300 \mathrm{~m}$ ) with insignificant dismemberment (from 0 to $100 \mathrm{~m} / \mathrm{km}^{2}$ ), the relatively undeveloped river-valley network (dismemberment density of $0.5-2.0 \mathrm{~m} / \mathrm{km}^{2}$ ), the various climatic conditions of karst formation during different periods, the high $\mathrm{CaCO}_{3}$ content (about 70-99.8\%), and the highly aggressive groundwater.

The paleogeographic and paleotectonic conditions were the reason for the formation of diverse types of surface and underground karst during the different geological periods. The changes of the paleogeographic circumstances caused the rearrangements of karst into continental, continental-marine and marine types. The beginning of karst formation in $\mathrm{N}$ Bulgaria started during the Eifelian, when Jurassic-type fold structures emerged as a result of the compression in single sections. The formed collision orogen was subjected to intensive karst denudation and erosion and plain karst originated. Typical plain and transition (marine-plain) karst was formed during the Triassic as a result of changing tectonic circumstances and local erosion bases due to repeated transgressive-regressive phases. The karstification was very intensive at the end of the Triassic and classical surface karst (karren, karrenfelds, dolines, uvalas, karst valleys and blind valleys) as well as storey-like and connected underground karst were formed. In the Middle Jurassic a shallow sea was situated on the territory of Bulgaria due to a regional transgression and the karst processes attenuated. In the end of the Bathonian the karstification was resumed at a high rate due 


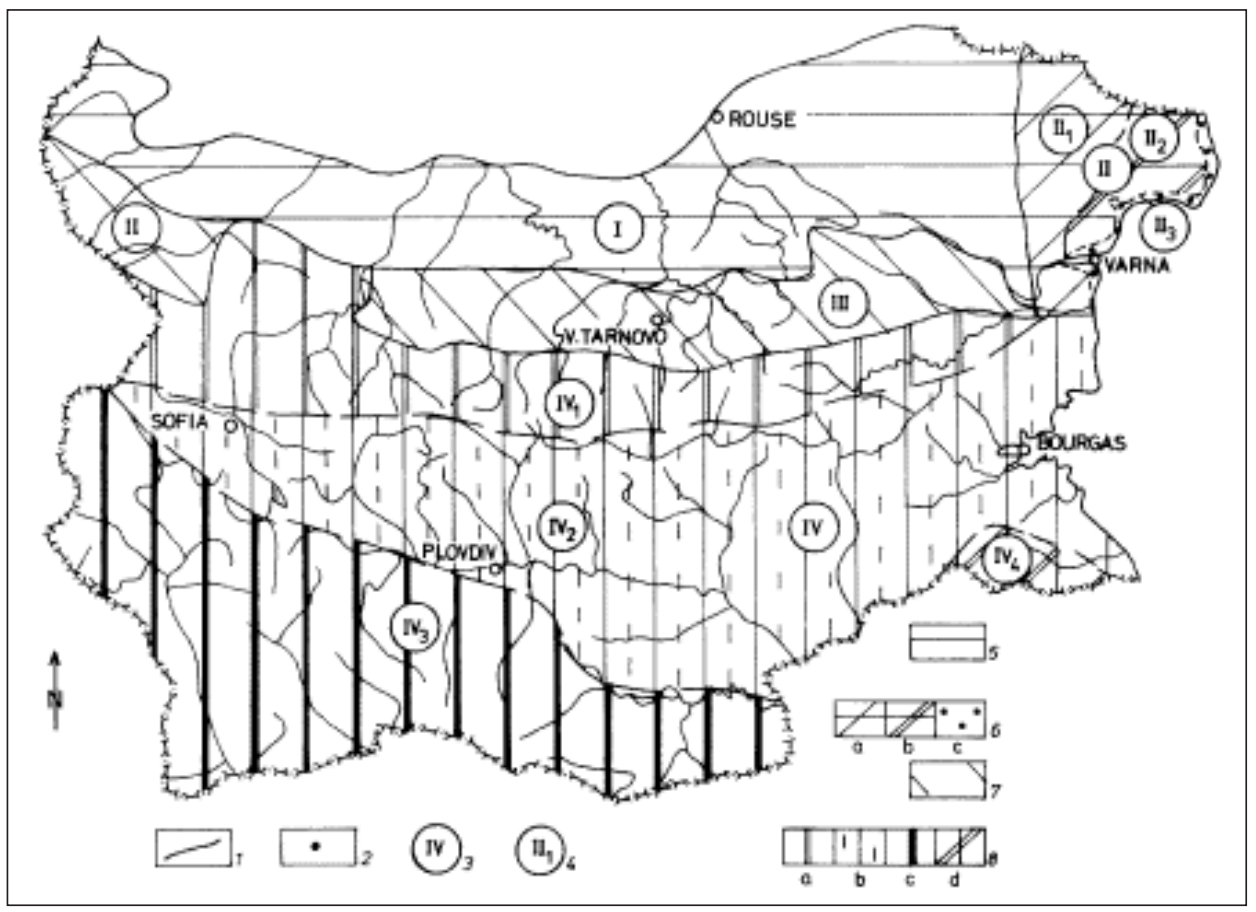

Fig. 1: A map of the karst types in Bulgaria: 1 - boundaries between the zones; 2 - karst spring; (3-4) - number of: 3 - the zone, 4 - the sub-zone; 5 - zone of plain karst (I - Danubian Plain); 6 - zone of the marine and transformed karst (II - Black Sea zone: 1 - plain, 2 - marine-plain, 3 - contemporary marine); 7 - zone of plateau-like (transition) karst (III - Fore Balkan); 8 - zone of mountainous, inter-mountainous and internal mountainous karst (IV - South Bulgarian zone: 1 - Stara Planina; 2 - Sredna Gora, low mountainous, fore-mountainous and internal basin karst, 3 - Rhodopes, 4 - Strandzha).

to the favourable climate. The paleogeodynamic circumstances were changeable during the Cretaceous. The Paleocene was characterized by simultaneous destructive processes and changes in the karstification rate, as well as by karst formation in the thick (up to $4000 \mathrm{~m}$ ) Cretaceous limestone at different levels. The paleokarst was repeatedly rejuvenated during the younger geological epochs in all of the formations, with the exception of the Beriassian-Valanginian one. The origin of neokarst was connected with the rearrangement of the Fore-Carpathian, Euxino-Caspian and Black Sea basins, the complete closing of the Fore-Carpathian basin and the entire drying of $\mathrm{N}$ Bulgaria. As a result the paleokarst surface and underground basins were entirely rearranged. There was a different degree of karstification. The neokarstification comprised a new level, reaching up to 200-220 m, which was very changeable for the different parts of the Moezian platform. Various underground forms emerged due to the tectonic activity and the erosion basis changes during the Quaternary, which corresponded to the stages of the river form complex development. The tectonic processes were the reason for the formation of connected karst, its rejuvenation and 
its partial to complete destruction, caused by catastrophic earthquakes (Angelova 1996, 2001). The karst in the Danubian Plain is a typical "resource" karst. The deposits of oil, gas, kaolin, fresh and mineral water, ore and mineral resources are affiliated to it (Stanev 1970, Stanev \& Trashliev 1989, Kehaiov \& Zyapkov 1995, Angelova 1999a and others).

Mountainous Karst. The karst included in the morphostructural units to the south of the Danubian Plain in contemporary plan refers to this type (Fig. 1). It is characterized by well expressed vertical zones (Popov 1970):

- Karst in the hilly hypsometric belt at an altitude of up to $600 \mathrm{~m}$;

- Karst in the low-mountain hypsometric belt at an altitude from 600 to $1000 \mathrm{~m}$;

- Karst in the middle-mountain hypsometric belt at an altitude from 1000 to $1600 \mathrm{~m}$;

- Karst in the high-mountain hypsometric belt at an altitude from 1600 to $2000 \mathrm{~m}$;

- Alpine karst at an altitude above $2000 \mathrm{~m}$.

The mountainous type of karst in Bulgaria is very specific. It is developed in marble, marbleized limestone, dolomites and limestone of different age. The karstification bears the features of mountain evolution and the lithological, structural and geodynamic peculiarities of the Balkan micro continent. It is differentiated into smaller units on the basis of a complex of reasons (Fig. 1).

The zone including the plateaux of the strongly deformed edge of the Moezian platform and the Stara Planina Mt. chain system is more specific. The boundaries between them are complex. The tectonic element is dominating in the evolution development of karst (Yaranov (ed.) 1959; Popov 1962b, 1970, 1976; Popov et al. 1965, 1969; Penchev et al. 1970; Markowicz et al. 1972; Ferrier \& Leblanc 1992; Angelova 1995, 1999c, 2002; Angelova et al. 2002c; Angelova \& Benderev 2002 and others).

Complexly arranged fault-fold forms were superposed at the background of the initial regional low-style syncline structure with east-west orientation. The different degree of karstification in the various geological epochs is due to the numerous local anticline and syncline structures with considerable relief dismemberment in historical geological time, the great differences in altitude (from 100 to $1500 \mathrm{~m}$ ), the different inclinations of the karstified slopes with often alternating values between $2^{\circ}$ and $90^{\circ}$, the greater density of the midstream network, the deeper erosion incision in the karst terrains, the higher precipitation, the often changed local erosion bases and the more rapid lithofacial changes and tectonic movements. As a result of all these reasons a typical plateau-like surface and underground karst type was formed at different levels, which was connected with the development of the Tethys and Paratethys basins and their transgressiveregressive phases. The Aptian-Urgonian, Triassic and Upper Cretaceous limestones are most strongly karstified. The vertical circulation of the karst water contributes to the its permeability to significant depths. The karst in the plateaux is developed in different structures - anticlines, synclines, monoclines. Numerous dolines, uvalas, blind valleys, poljes, caves and shafts are observed in the Batulia anticline at a denudation level of 450-500 m. The depth of the Bezdannia Palin exceeds $100 \mathrm{~m}$. The most complexly arranged flood cave system of the Vit River is situated here with discharge at the biggest karst spring Glava Panega. The most typical karst in the syncline structures is in the Strazhata syncline, where Aptian sandstones and marls cover the several horizons of the Aptian-Urgonian limestones. More than 26 caves have been discovered in the Strazhata Plateau up to now, the Bacho Kiro cave being more than $3 \mathrm{~km}$ long. The karst in the Shoumen 
Plateau includes surface and underground karst forms. The surface karst is represented by karren, karrenfelds, dolines, uvalas, karst valleys (dry valleys, semi-blind and valleys), and karstified rock crowns. The underground karst forms are represented by 34 caves and shafts. Their length varies from 10 to $3000 \mathrm{~m}$ and their depth from 10 to more than $100 \mathrm{~m}$. The structural predetermination of karst depends on the morphology of the initial syncline structure and the subsequent tectonic deformations as well as on the small thickness of the limestone, thus determining the character and rapid development of the karst process and its cycle. The Shoumen Plateau is a model for the development of independent and interconnected surface and underground karst systems. They are at different stages of development. The karstification started after the Atian tectonic phase. The karst in the Fore Balkan is also of the "resource" type. One of the biggest aquifer in Bulgaria is connected with it, as well as oil, gas, ore and mineral resource deposits.

The karst in the Stara Planina Mt. occupies about $20 \%$ of the territory of the mountain. It is covered and bare paleo- and neo-karst. It is developed mainly in the Triasssic and in the Cretaceous. The favourable physical geographic conditions, the different inclinations of the karstified slopes, the configuration of the mountain systems, their plastics, interrelationships between the endo- and exogeodynamics, as well as the high values of the vertical dismemberment (from 100 to $1200 \mathrm{~m} / \mathrm{km}^{2}$ ), the broad variation range of the river network from 1.5 to more than $5.0 \mathrm{~km} / \mathrm{km}^{2}$ lead to the entire drainage of the surface and underground karst water and its intensive exchange, influenced also by the different amount of precipitation. As a result of complex geodynamic reasons, the karstified rocks are in complex lithological and tectonic discordance. The karst in W Stara Planina is very typical in this respect. It is of great interest for researchers, since it is of the classical surface and underground type and it contributes to the solution of many fundamental and practical problems (Radev 1915; Popov 1964, 1970; Angelova 1999b,c; Angelova et al. 1995, 1999, 2002; Kostov 1997 and others). The differing in morphology structures (folded and faulted), rank and dynamics structures also contribute to the development and activation, as well as to the uncovering and rejuvenation of karst. The vertical and horizontal tectonic movements are the reason for the surface and groundwater circulation and for the creation of diverse surface and underground karst forms and karst rejuvenation. The contemporary karst is of the "oriented" type and is closely connected with the river basin development. The process of the valley karst formation was started before the Upper Pliocene. The process of karst formation is uncompleted. There are 19 cave regions in the Stara Planina Mt. (Popov 1970). The deepest shafts have been established here with depths exceeding $200 \mathrm{~m}$.

The karst in the Rhodopes, Strandzha, Vitosha, Vlahina, Osogovo, Slavyanka, Pirin and the other mountains is developed in Proterozoic marbles and dolomites and in Triassic, Jurassic and Paleogene limestones. Paleo- and neo-karst of the volcanic type is observed in the E Rhodopes. It bears the features of the geodynamic development of the mountains and of the specific physical geographic conditions. This paleo- and neo-karst is described by Popov (1962a), Markowicz et al. (1972), Benderev \& Angelova (1999), Angelova (2002a) and others. The karst processes were additionally developed by the glaciers and the frost weathering because of the more intensive neotectonic movements and their shifting to higher altitudes in Pirin and partially in Vitosha, W Rhodopes, Slavyanka and Osogovo Mts. This is very typical for the karst in the Pirin Mt., where many shafts have been formed at the cirque bottoms. The contemporary karst process is not completed. Except for the well-represented surface karst in the W Rhodopes (karren, dolines, 
valleys, canyons, rock bridges, etc.), more than $20 \%$ of the caves in Bulgaria have so far been discovered here. The spatial connections between the surface and underground karst vary within a broad range. The paleokarst is of the "resource" type and rich deposits of polymetal minerals and water are found in it. The beginning of karst formation in the Chepelare region (Angelova 2002b) is connected with the origin of gravitation overthrusts and olistostrome stacks in the beginning of the Paleogene. The faults controlling the paleokarst development spread in NW-SE direction $\left(130-160^{\circ}\right)$ and the faults controlling the neokarst development spread in NW direction (300$315^{\circ}$ ). There is fissure water of high flowrate in the zones of intensive karstification. Paleoseismic disturbances accompanied by gravitation blockages, terrain collapse and interruptions in the rivervalley network are encountered in the investigated region. The paleoseismic events have occurred from the Plio-Pleistocene to the present. They are localized in single sections and can be used for the understanding of the contemporary geodynamics in one of the most seismically active zones in Bulgaria.

There is a mosaic of mountains and basins between and in the mountains in the area between the Stara Planina Mt. and the Rila-Rhodopes massif. Specific karst regions are situated in it, which bear the features of a specific geodynamic space, morphology, geological structure, etc. The best-studied morphogenesis of paleo- and neo-karst in these regions is in the area of Kremikovtsi, Vitosha and Strandzha (Yaranov (ed.) 1959; Stanev 1970; Popov 1970, 1976; Stanev \& Trashliev 1989; Benderev \& Angelova 1999; Angelova 1999b, 2002a and others). This karst is structurally predetermined and in most cases it is multi-storeyed and affiliated to the valley systems. Several stages in karst morphogenesis have been distinguished in the development of the Vitosha karst (the Bosnek karst region): thrusting of Triassic limestone and dolomites over the volcanic of the Vitosha Mt., active vertical tectonic deformations that have led to the formation of the Vitosha and Golo Bardo Mts.; strong tectonic disturbance and erosion activity of the Strouma River, which have brought to the origin of the biggest labyrinth (7-storeyed and more than $17 \mathrm{~km}$ long) karst system in Bulgaria - "Douhlata". The karst process is not completed.

Marine Karst. Its development is in close connection with the development of the EuxinoCaspian and Black Sea basins during the Neogene and the Quaternary (Yaranov (ed.) 1959; Markowicz et al. 1972; Popov \& Mishev 1974; Angelova 1999a, 2001a,b,c; Angelova \& Spasov 2002; Angelova et al. 2002). The changes in the geodynamic circumstances and the transition of the Eastern Bulgarian territories from the marine carbonate platform into the subaqual and aubareal plain and vice versa in connection with the regional extension, as well as the presence of rocks with high $\mathrm{CaCO}_{3}$ content (up to $99 \%$ ), have led to the formation of specific karst from the marine, mixed, plateau-like and plain karst. The karst process proceeds at several levels. The paleokarst forms are observed in boreholes at more than $2000 \mathrm{~m}$. The neokarst forms (caves and cave systems filled with fresh karst water) are found at different levels from 70 to $150 \mathrm{~m}$ under the contemporary sea level. Cave levels are observed on the land in the littoral part at sea level as well as at heights of 2, 5, 10, 20,50 and $70 \mathrm{~m}$. The Quaternary loess complex fossilizes a developed karst Lower Pleistocene morphological complex without interruption in karst genesis. The contemporary karst morphogenesis is most active in the littoral zone, where contemporary marine and marine-plain karst is developed.

The karst wetlands (Fig. 2) are important elements of the karst landscape. The interest in their study in Bulgaria as a specific karst type has been increased recently. 


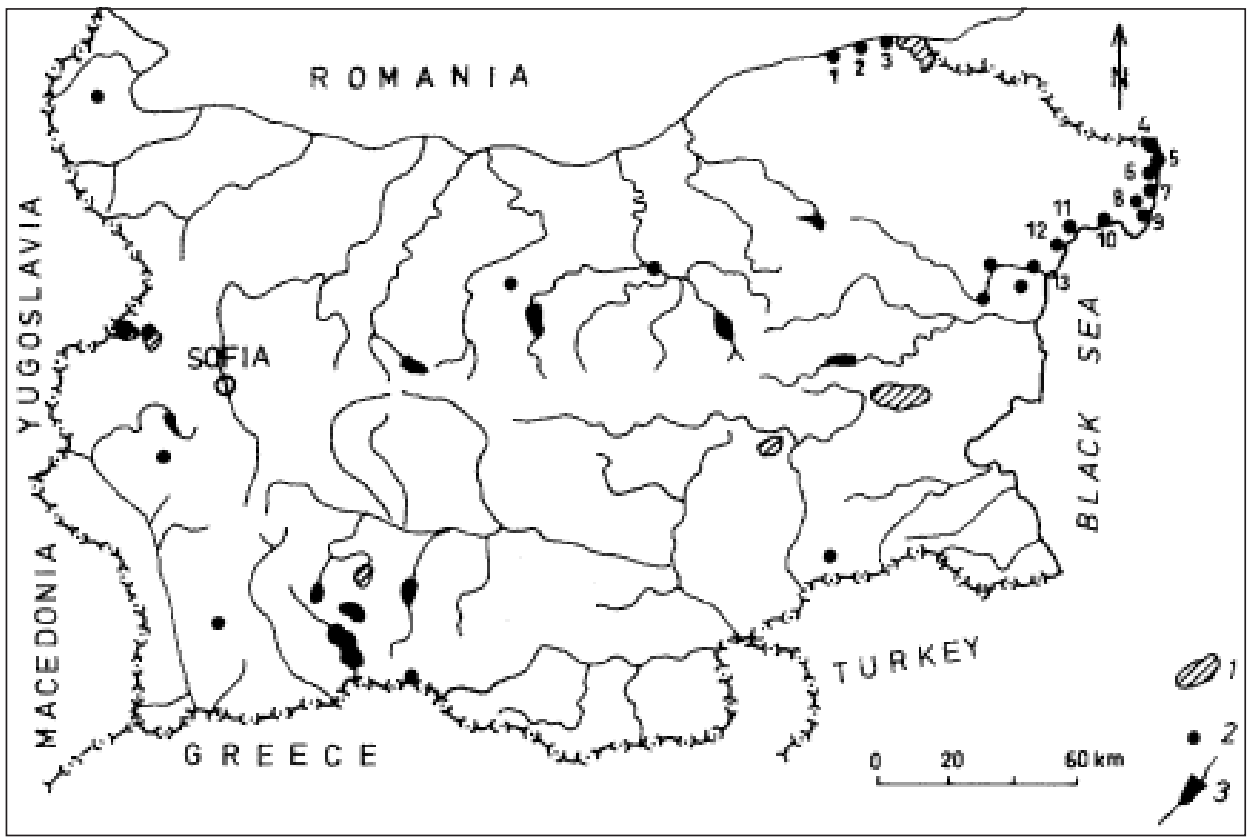

Fig. 2: Karst wetlands in Bulgaria: 1 - dried natural wetlands; 2 - natural marshes and lakes; 3 - artificial lakes (dams).

For the present, the "Sreabarna" and some other karst wetlands along the Dobrudzha coast are best studied (Popov \& Mishev 1974; Angelova 1996, 2000, 2001abc, 2002; Angelova et al. 2002). Most of the natural wetlands (lakes, marshes, lagoons, limans, glacier landslide lakes and marshes) were formed during the Upper Pleistocene or at the Holocene-Pleistocene boundary. They are of different genesis. The artificial lakes (dams) in karst terrains are included to them recently.

Sufficient amount of information has been collected in recent years in Bulgaria about the origin of the gravitation type of karst (Angelova 1995, 1999c, 2001a,b,c, 2002ab). It represents the result of catastrophic paleoseismic events.

\section{CONCLUSION}

Karst in Bulgaria comprises a considerable area of the territory of the country. It is distributed in carbonate bodies with a different structure, dynamics and spatial relationships. New zoning of karst is being carried out for the Bulgarian territory. It is divided into: plain; marine and transformed marine karst into plain and plain-marine karst; plateau-like karst; mountain and intermountain karst; karst wetlands and gravitation karst, provoked by catastrophic earthquakes. The further study of karst morphogenesis in Bulgaria will contribute to the solution of problems related not only with practice but also with the solution of some debatable problems concerning karst evolution. 


\section{REFERENCES}

Angelova, D. 1995: Neotectonics and Geodynamics of the Madara Plateau. Problems of Geography, 2, 75-84 (in Bulgarian).

Angelova, D. 1996: Neotectonic and Geomorphological Characteristics of the Western Part of the Aydemir Lowland, Silistra District. Geologica Balcanica, 26, 3, 53-57 (in Bulgarian).

Angelova, D. 1999a: The Paleokarst in Northeast Bulgaria Related with Kaolin Deposits. In: Etudes de geographie physique, Travaux 1999, Sup. ${ }^{\circ}$ XXVIII, Cagep, Universite de Provence, France, 19-23.

Angelova, D. 1999b: The Karst in the Region of the "Kremikovtsi" Mine, Bulgaria. In: Etudes de geographie physique, Travaux 1999, Sup. n XXVIII, Cagep, Universite de Provence, France, 25-28.

Angelova, D. 1999c: Tectonic Prerequisites for the Karst Development in the Stara Planina Iskar River Gorge (Bulgaria). Proc. of the National Scientific Conf. on Problems of Karst and Speleology, Sofia, March 1999, 43-50 (in Bulgarian).

Angelova, D. 2000: Comparative ecological and paleogeographycal investigations of the "Srebarna" and "Durankulak" lakes (Bulgaria). In: Le Piamure, Labanti, Bologna, Italy, 31-34

Angelova, D. 2001a: Main Stages in Karst Morphogenesis, Northeast Bulgaria. Acta Geologica Sinica, J. of the Geol. Soc. of China, vol. 75 (in press).

Angelova, D. 2001b: Paleoseismic Events in Karst Terrains along the Northern Bulgarian Black Sea Coast. Acta Geologica Sinica, J. of the Geol. Soc. of China, vol. 75 (in press).

Angelova, D. 2001c: Paleoseismic Studies of the Moezian Platform (Bulgaria). Risk Effect of the pre-Historic Paleoseismic Dislocations. In: Riviera 2000 - Tectonique active et geomorphologie, Revue d'Analyse Spatiale, No spécial 2001, France, 9-15.

Angelova, D. 2002a: The Bosnek Karst Region (Bulgaria) - a Phenomenon and Geological Problems. Proc. of the $4^{\text {th }}$ Symp. On Karst Protection, 3-6 November 2000, Despotovac, Yugoslavia (in press).

Angelova, D. 2002b: Paleokarst in Radyuva Planina, Sdmolyan District (Bulgaria). Proc. of the $4^{\text {th }}$ Symp. On Karst Protection, 3-6 November 2000, Despotovac, Yugoslavia (in press).

Angelova, D., Benderev, A., Baltakov, G., Ilieva, I. \& Nenov, T. 1995: On the Karst Evolution of the Stara Planina Iskar River Gorge. Review of the Bulg. Geol. Soc., 56, 3, 111-124 (in Bulgarian).

Angelova, D., Benderev, A. \& Kostov, K. 1999: On the Age of the Caves in the Stara Planina Iskar River Gorge, NW Bulgaria. In: Etudes de geographie physique, Travaux 1999, Sup. $\mathrm{n}^{\circ}$ XXVIII, Cagep, Universite de Provence, France, 29-35.

Angelova, D. \& Benderev, A. 2002: Karst and tectonics in the Iskar River Gorge (Bulgaria). Proc. of the $4^{\text {th }}$ Symp. On Karst Protection, 3-6 November 2000, Despotovac, Yugoslavia (in press).

Angelova, D. \& Spasov, K. 2002: Paleo- and Neokarst in the Loudogorie Region and Dobrudja (Bulgaria). Proc. of the $4^{\text {th }}$ Symp. On Karst Protection, 3-6 November 2000, Despotovac, Yugoslavia (in press).

Angelova, D. et al. 2002: Geomorphological Maps of Bulgaria in Scale 1:100000. Sheets Kozloduy, Gigen-Knezha, Byala Slatina, Pleven-Nikopol, Alexsandria-Svishtov, Popovo, Razgrad, Novi Pazar, Dobrich, Shabla-Balchik, Provadia, Shoumen, Silistra and Explanatory Note to Them. Ministry of Environment and water (in press). 
Benderev, A. \& Angelova, D. 1999: Evolution of Karst in the Southern Part of the Vitosha Mountain, Bulgaria. Theoretical and Applied Karstology, vol. 11-12, 1998-1999, 75-82.

Ferrier, C. \& Leblanc, J.-C. 1992: Etude du complexe karstique Prohodna-Temnata: morphologie, genese et evolution. Temnata cave. Excavations Karlukovo Karst Area, Bulgaria (Kozlowski, J.K., Laville, H. \& Ginter, B. (eds.)), Jagellonian University Press, Krakow, Poland, Vol. 1, Part 1, 31-48.

Kehaiov, T., L. Zyapkov. 1995: Chemical Characteristics of karst underground waters in Bulgaria.-Problems of Geography, 1, 22-31 (in Bulgaria)

Kostov, K. 1997: Karst Morphology in Bazovski Part of the Vratsa Mountain (West Stara Planina, NW Bulgaria). Proc. of the $12^{\text {th }}$ Int. Congr. on Speleology, August 10-17, 1997, Switzerland, 1, 409-412.

Krastev, T. 1974: Morphology of the Buried Karst in the Loudogorie. Problems of Geography, 1, 43-44 (in Bulgarian).

Krastev, T. 1978a: Adolescent Karst Morphology in the Region between the Beli Lom and Malki Lom River Valleys. Bulletin of the Bulg. Geogr. Soc., 16, 23-32 (in Bulgarian).

Krastev, T. 1978b: The Significance of the Paleoclimate for the Development of the Buried Karst in Russe and Razgrad Regions. Bulletin of the Bulg. Geogr. Soc., 15, $45-49$ (in Bulgarian).

Markowicz, M., Popov, V. \& Pulina, M. 1972: Comments on Karst Denudation in Bulgaria. Geographia Polonica, 23, 111-138.

Penchev, P., Popov, V. \& Zyapkov, L. 1970: Karst in the Northern Part of the Middle ForeBalkan. Problems of the Paleo Geomorphological Development of Bulgaria, Bulg. Acad. of Sci., vol. 1, Sofia, 83-91 (in Russian).

Popov, V. 1962a: Morphology of the Golemia Kazan Circus in the Pirin Mountain. Review of the Geol. Inst., 6, Bulg. Acad. of Sci., 85-100 (in Bulgarian).

Popov, V. 1962b: Morphology of Karst in the Region between the Vit and Batulka River Valleys. Review of the Bulg. Geogr. Soc., 3, 21-35 (in Bulgarian).

Popov, V. 1964: Morphology and genesis of the "Ledenika" Cave. Review of the Geogr. Inst., Bulg. Acad. of Sci., 8, 77-87 (in Bulgarian).

Popov, V. 1970: Distribution of Karst in Bulgaria and Some of Its Features. Review of the Geogr. Inst., Bulg. Acad. of Sci., 13, 5-19 (in Bulgarian).

Popov, V. 1976: Zoning of Caves in Bulgaria. Problems of Geography, 2, 14-24 (in Bulgarian).

Popov, V., Penchev, P. \& Zyapkov, L. 1965: Morphology and Hydrology of Karst in the Northern Part of the Fore Balkan between the Yantra and Ossam Rivers. Review of the Geogr. Inst., Bulg. Acad. of Sci., 9, 69-93 (in Bulgarian).

Popov, V. \& Zyapkov, L. 1969: Karst in the Northern Part of the Fore Balkan between the Iskar and Vit Rivers. Review of the Geogr. Inst., Bulg. Acad. of Sci., 12, 47-613 (in Bulgarian).

Popov, V. \& Mishev, K. 1974: Geomorphology of the Bulgarian Black Sea Coast and Shelf. Publ. House of the Bulg. Acad. of Sci., Sofia, 267 p. (in Bulgarian).

Radev, J. 1915: Karst Forms in the Western Stara Planina Mountain. Annual of the Sofia Univ., 10-11, 149 p. (in Bulgarian).

Stanev, I. 1970: Ancient and Contemporary Karst in the Upper Jurassic - Lower Cretaceous Aquifer in North Bulgaria. Review of the Bulg. Geol. Soc., 31, 2, 241-249 (in Bulgarian).

Stanev, I. \& Trashliev, S. 1989: Paleokarst of Bulgaria. In: Paleokarst. A Systematic and Regional Review. Elsevier, 217-230.

Yaranov, D. (ed.) 1959: Karst Underground Water in Bulgaria. Tehnika, Sofia, 284 p.(in Bulgarian). 